\title{
NATIONAL PARK CITY: SALUTOGENIC CITY?
}

\author{
TIM TOWNSHEND, MAGGIE ROE, CLIVE DAVIES \& QIANQIAN QIN \\ School of Architecture, Planning and Landscape, Newcastle University, UK
}

\section{ABSTRACT}

In 2017 the London Mayor's Office launched plans to make London the world's first National Park City, one of the greenest cities on earth. What appears to be allied to the long standing "All London Green Grid" includes plans to increase physical greenspace for exercise, socialisation and relaxation, as well as reduce waste and tackle issues like air pollution. In parallel an initiative to exploit National Parks for national health has also been launched in England. Thus far the discourse about these two initiatives has been separate. Moreover, while the hype around them sounds enticing, there is little robust information on how they will be realised, nor what substantive benefits may be delivered. This paper takes a step back. In particular it explores the foundations on which National Park Cities might be built - including examining another contemporary and pertinent concept, that of National Urban Parks i.e. combining well-established concepts of National Parks, yet within urban settings. It will question what health and well-being benefits might accrue to any future Urban National Park, as well as exploring what might be the best basis on which cities might be selected for this accolade and by whom. Based on these explorations it will further seek to answer whether or not National/Urban Park Cities will bring closer the realisation of the salutogenic city concept.

Keywords: National Park City, Urban National Park, salutogenic cities, green infrastructure.

\section{INTRODUCTION}

Although the precise origin of the term "National Park" is somewhat disputed, it is generally associated with the move to conserve and protect areas viewed as "wilderness" in mid-19th Century mainland United States of America (USA). Described as America's "best idea" [1], the term is now used in many countries across the globe and covers many different types of landscape. In 1948 the International Union for Conservation (IUCN) was founded to encourage international cooperation and provide scientific knowledge to guide conservation. Many National Parks are recognised under the IUCN protection areas categories system as category II "National Parks" - areas that are protected and mainly managed for ecosystem protection. UK - and indeed many European National Parks - however, fall under category V "Protected Landscape/Seascape", a "protected area where the interaction of people and nature over time has produced an area of distinct character". These category V National Parks, therefore, generally contain significant human settlements, and moreover attract millions of visitors for the purposes of "escape, adventure, enjoyment, inspiration and reflection" [2].

Over the past year in England parallel debates have evolved around the future of National Parks. Firstly around the possibility of developing Urban National Parks (UNPs) - largely prompted by London Mayor's Office's declaration that it wants to make London the world's first "National Park City" (NPC) [3]; and secondly about exploiting the potential of England's National Parks to improve physical health and mental well-being. This latter initiative was launched through a partnership between Public Health England and England's ten National Parks under the banner headline of "National Parks for National Health" [4]. Thus far these two narratives have been separate. The aim of this paper (in part) is to consider the implications of them coming together. Could UNPs be a way of addressing contemporary urban health problems and inequalities? Could they, for example, be a way of delivering salutogenic city concepts? 


\section{THE SALUTOGENIC CITY}

It is over 25 years since Aaron Antonovsky proposed the theory of salutogenesis, or the salutogenic model to represents a paradigm change in health promotion, focusing on the factors that facilitate or optimise health, rather than on the treatment or prevention of illhealth and disease (the pathogenic model). During the same period much research has emerged that suggests the built environment (i.e. covering all aspects of urban areas) can in itself support, or constrict healthy lifestyles and moreover that we have innate reactions both positive and negative in health terms - to environments over which we are able to exert little control [6]. Turning to the objectives of IUCN Category V: Protected Landscape/Seascape, much is made of the interaction between humans and the landscape, as well as natural and cultural heritage. It is therefore worthwhile briefly considering these priorities in relation to health, well-being and the salutogenic properties of the built environment.

Over the same period Green Infrastructure (GI) has been developed as a contemporary approach to the conceptualisation and management of landscape resources. While there is no one definitive definition of GI, Natural England - the government's advisory body for the natural environment - states that "Green Infrastructure is a strategically planned and delivered network comprising the broadest range of high quality green spaces and other environmental features" [7]. And while some authors may take issue with this definition, the promotion landscape connectivity, while supporting ecological and human interests are common themes in most descriptors. The following section focuses on existing research exploring aspects of GI and health and well-being outcomes.

\subsection{Green infrastructure for human health and well-being}

The health supportive qualities of GI have received significant attention in the last few decades, with a key underpinning concept of "therapeutic landscape" developed by Gelser [8], [9]. Gelser divided dimensions of therapeutic landscape into three, physical, spiritual and social. These he suggested combined to create holistic notions of health. The early development of Kessler's concept focused on places perceived as "natural landscapes", or places of natural beauty that people seek out for relaxation and to get away from it all, such as the Lake District, (Fig. 1). However much research has recently emphasised that landscapes like the Lake District are actually far from natural, they are effectively man-made. This has raised the question of whether other types of man-made landscape are health promoting - in other words not just ones which simulate, or reinterpret (based on broad cultural influences - art literature and so on) notions of natural wilderness. The possibility of more obviously man-made - in other words built/urban environments - offering aspects of therapeutic landscape has been brought into focus [10].

In relation to this, the health supportive properties of GI are now well established. Hartig et al. [11] identify 4 key mechanisms, stress reduction and restoration; opportunities for increased physical activity; opportunities for greater socialisation; and improved environmental quality, for example cleaner air and water or reducing urban heat island effects - potentially reducing heat morbidity. Each mechanism has its own considerable body of literature which can only be briefly overviewed here. However in terms of stress reduction and restoration there are two key theorisations, Ulrich's psychoneuroendocrine processes [12], [13] and Kaplan's Attention Restoration Theory ART [14], [15]. Ulrich's work suggests that there are innate processes within the brain that result in stress levels been reduced when people come into contact (even by simply viewing) a natural environment. ART focuses on 


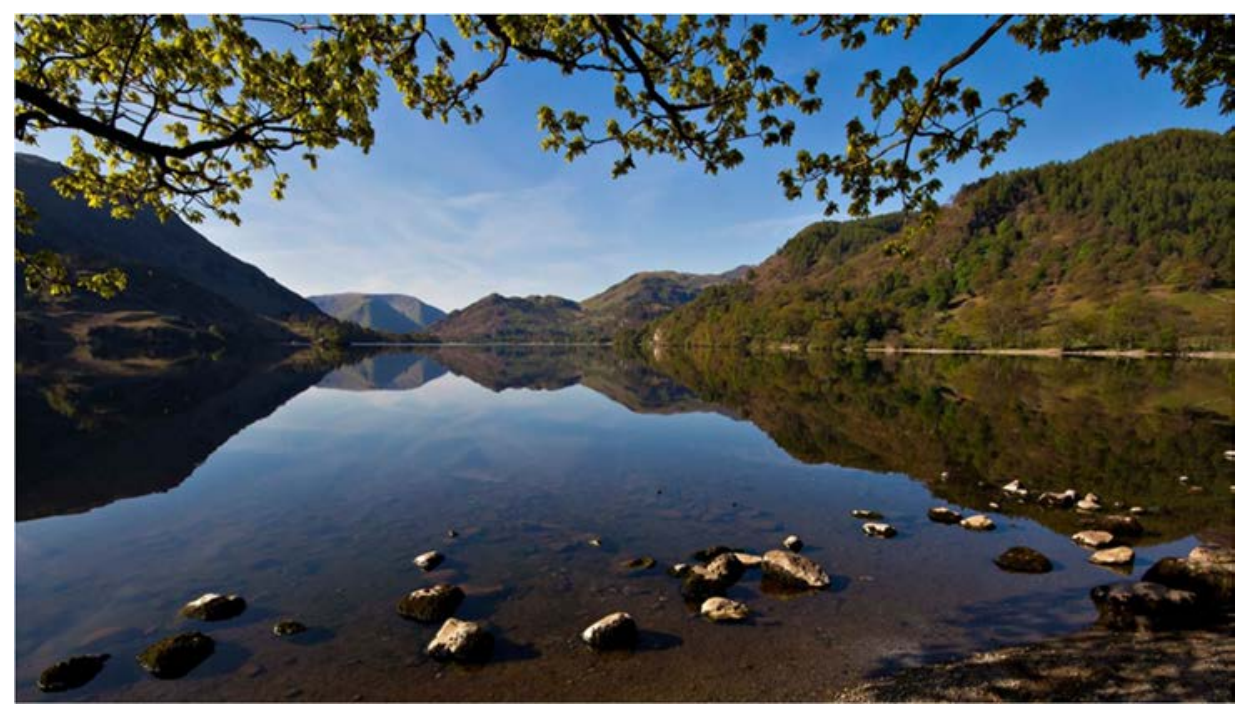

Figure 1: Ulswater, Lake District National Park, a "man-made" landscape.

the way in which natural environments remove people from the stresses of everyday modern life providing interest without effort which restores mental fatigue.

In terms of physical exercise many studies have focused on the role the GI to provide settings for elective activities [16]. Urban parks for example are particularly important because they are publicly accessible and provide settings and facilities which appeal to a broad range of uses and are generally free to access. In terms of increased social well-being again GI is important because it provides a range of attractive setting for interaction and a heterogeneous range of users [17]. The final mechanism relates to improved environmental quality, though for example the ability of plants to filter out pollutants and reduce heat island effects. The health benefits of Urban Forests, for example, have been subject to many studies [18]. Urban Forestry is a collective term used in both practice and research to describe the management of all the trees, shrubs and associated urban open spaces [19]. For example, the contribution urban trees make in respect of cooling urban areas during high-temperature episodes is one notable area and which in turn can lead to reduced heat stress, strokes and mortality in vulnerable groups as well as providing thermal comfort [20]. It should also be noted that Urban Forests are significant contributors to city landscapes and in many instances will form the greater part of a candidate National Park City's green infrastructure [21].

Many studies exploring the links between human well-being in GI also contain considerable water bodies within their remit [22] however the influence of water has not always been explicitly/separately examined. It is possible that spaces that are primarily blue as well as green, including urban blue spaces possess therapeutic qualities. Moreover it is possible that the presence of water may include added benefits. Water has been a prominent element in healing gardens and similar therapeutic settings as it is well known to provide positive distraction for visual, auditory and olfactory senses [23], [24]. The calm sounds of water, for example are restorative [25] water bodies have been associated with stress reduction, mood enhancement and general enjoyment and views of water identified as potentially benefit for perceptions of personal health [26]. However, it also has to be acknowledged that the presence of water bodies can be a double edged sword. For example, 
storm water run-off after heavy rain can carry increased contaminants and high levels of bacteria. Some studies have shown a direct link between heavy rainfall and outbreaks of waterborne diseases such as E. coli. Flood risk and damage to properties have shown to have negative effects on mental health, increasing mental stress and depression, moreover effects within communities can be long-lived. [27]. Finally the ever present danger of drowning is a concern, in the UK in particular in recent years there have been a number of unexplained cases of drowning cities with major rivers, particularly involving university students [26].

\subsection{Biodiversity, humans, wildlife and well-being}

It has been established that a disconnection with nature results in reduced consideration of biodiversity and wildlife conservation, however, the reverse is also true and where people are engaged with nature they will be more eager to preserve it locally and supportive of interventions to do so. One motivational pathway that has yet to be fully explored is the relationship between levels of biodiversity and human well-being. Luck et al for example, related a positive relationship between neighbourhood well-being and the richness and abundance of birdlife. Other research suggests that people who interact with GI with higher biodiversity have higher levels of perceived well-being [28]. And research has also shown that people take more exercise in areas of high higher biodiversity [29] The exact reasons behind these correlations are not yet known, however one possible explanation is that human brain finds stimulation from the morphological features of flora and fauna, therefore it would follow that places with greater biodiversity will have higher levels and combinations of morphological features and therefore have a stronger impact on mental processes.

Physiological impacts on children may be particularly important. Research has shown that children who spend time in GI are more likely to develop healthy immune systems. Here two mechanisms are important, firstly early exposure [30] and furthermore exposure to a diverse range of micro-organisms [31]. More generally children who do not spend time outdoors in GI may develop Nature Deficit Disorder (NDD) [32] or even suffer from vitamin D deficiency which can cause a bone disorder, commonly known as rickets.

\subsection{Historic environments and mental health}

A further issue that is worthy of consideration in relation to UNPs is that between historic built environments and mental health. As far back as the 1970s research suggested that modernist townscapes produced feeling oppression and disorientation [33] while historic townscape induced stability and acted as a buffer against the changes and stresses of modern life [34]. More recently this strand of research has led to the concept of "ontological security" or the idea that familiar historic streetscapes provide cues that lead to improved mental wellbeing [35]. Such reactions are often encapsulated in the concept of "place attachment" and research has established that in areas of stronger place attachment people have increased perceptions of mental health and well-being [36]. One proposition is that historic environments induce greater feelings of place attachment through a process called "spontaneous fantasies", or an ability of pattern to spontaneously create vignettes of the past in people's mind, moreover this line of research emphasises that it is the overall historical landscape that is important not just individual historic buildings [37].

\subsection{Socio-economic activity and health}

A final pertinent aspect of IUCN objectives refers to providing opportunities for socioeconomic opportunity; this too has links to health and well-being. Having good social 
networks and opportunities for employment and prosperity are known to positively impact mental health. The opportunity that GI provides as a backdrop to social life and social capital has already been mentioned [17]. However there are a seeming myriad of ways in which GI contributes towards socio-economic activity and thereby to health and well-being. These range from providing high quality environments that encourage investment in both physical and economic terms [38] to increasing the value of property [39] and providing employment through activities such as urban forestry [40]. However less evidenced but equally significant could be cost saving reductions to the National Health Service (NHS), for example through prescribing less expensive alternative to medication, such as green exercise for so-called lifestyle diseases (such as type II diabetes), and reducing sick pay (provided by employers) and loss of work and productivity [41].

\subsection{Summary}

In essence therefore a designation that protects landscape, promotes biodiversity and conserves historic environments - along the line of current English NP practice should be positive for health and well-being outcomes. Our cities have some of the worst health profiles, for example in relation to so-called lifestyle diseases (obesity, Type-II diabetes and so on). Moreover health inequalities - the difference in health profile between rich and poor urban areas have increased in recent decades [42]. An UNP designation could potentially improve health across an urban areas - for example, through improved air quality - but also reduce health inequalities by upgrading GI in poorer areas.

\section{URBAN NATIONAL PARKS FOR NATIONAL HEALTH?}

The preceding sections would therefore suggest that there is considerable scope for improving health in urban areas through an UNP designation. However while there has been much hype about the possibility of turning London into a UNP, or as the London Mayor's Office has stated the world's first "National Park City" [3], what documentation exists provides a poor articulation of the conceptual basis for the idea. There is also very information available concerning the National Parks for National Health scheme. A "joint accord" between ten English National Parks England and Public Health England [4] was launched in 2017; this set out aspiration for policy, investment and creating linkages; but concrete evidence of change being delivered thus far is hard to find. An initial examination of London's National Park city concept seems to suggest that much of the discourse is superficial with few substantive proposals behind it [43]. It appears more of a rebranding exercise of the existing "All London Green Grid" [44], which is already an actionable existing strategy.

Moreover, and despite some of the claims made in relation to the London National Park City proposal, there are in fact National Parks with in an urban setting, however it would appear that thus far these have not had health priorities as a particular focus. For example, in Sweden, Stockholm's Ulriksdal-Haga-Brunnsviken-Djurgården National Urban Park or "Ecopark" which consists of $19 \mathrm{~km}^{2}$ of land and $8 \mathrm{~km}^{2}$ of water including the Fjäderholmarna Islands [45]. The primary function was to try and protect the area from development pressures that were threatening the area in the 1990s and identify or label a function which would counteract the idea that this was vacant land. The park is regarded as a place of recreation, but broader aspects of health and well-being receive scant attention, although picking up on the earlier theme of place attachment, a great deal of effort has been put in to developing the parks identity [46]. Similarly in the case of Jamaica Bay New York, the only national park that New Yorkers can "reach by cab" [47]. While narratives have focused on environmental 
improvement and the health of the eco-system, the possible impacts on human visitors have yet to be explored.

\section{DISCUSSION AND CONCLUSION}

The situation thus may be summarised thus, in theory there could be considerable health and well-being benefits derived from UNP status - indeed approaching salutogenic ideals. However the exact nature of UNP within the UK context is unknown, there are no directly comparable international examples that have measured health/well-being impacts and England's own $\mathrm{NP}=\mathrm{NH}$ scheme has yet to bear fruit - so unfortunately this does not necessarily provide much sound foundation for future debate.

One possible way forward would be to propose a more scientific and technical framework within which the future of UNPs might be set out. This should take into consideration the existing evidence (such as there is) and consider the ICUN's existing categories for protected areas. Firstly terminology needs clarification - at present NCP, UNP and alternately National Urban Parks (NUP) appear in literature, and are used to variously/interchangeably to mean a park worthy of national recognition, located in an urban areas - which may or may not have continuous green cover but is considered as a specific location - or, to a part of a, or whole, city, being covered by national park status; in other words containing a multitude of green, blue and built up spaces. Thus location of boundary and whether the park is considered a single entity, or a collection of places may be one element under-pinning terminology.

Scale is another important issue. It might be argued that it would be inappropriate for a smaller "second tier" city should have to compete with a city such as London, with its global reputation and bountiful resources, on the same criteria for park status. A series of categories, for example based on population, or status - second tier, regional capital, national capital and/or mega-city, might be appropriate. Each sub-category could have its own criteria for nomination.

Quantity versus quality of greenspace is a further classification. Should NCP/UNP be defined as suggest in the case of London, by a minimum of $50 \%$ land as greenspace, or should a measure of the quality of greenspace be introduced? If it is recognised that some elements of urban greenspace are unusable - such as land adjacent to busy highways, while other greenspaces lie in private hands and so on, should these areas be considered as significant as for example public parks? And therefore should all greenspace of whatever type be counted as equal? A system that was based on quality, and moreover accessibility, while ostensibly more difficult to quantify, may be significantly more meaningful.

Finally should complimentary targets be introduced through NCP/UNP status? For example, addressing health inequalities might be one possibility. In this case $\mathrm{NCP} / \mathrm{UNP}$ status might require authorities to spend more in poorer areas to ensure that green space provision - both quantity and quality - was brought up to the standard of that in its wealthiest neighbourhoods.

More work and serious examination of the concept is undoubtedly needed on multiple fronts, for the moment many key questions remain unanswered, not least how much buy-in there would be from the general public, how democratic these nominations would be and what governance arrangements would need to be put in place. As outlined near the beginning of this text National Parks have a strong sense of identity in the national psyche, they are deeply embedded in highbrow and popular cultural works and behaviour towards them and within them governed by social mores that run to the heart of national identity. The acceptability - at least initially - of UNPs to the general public may well depend how they relate to this framework. 
Finally, while there may be no comparable international case studies, there is undoubtedly much to be learnt by looking at the way in which the concepts and principles of national parks have developed over the last 100 years - across the globe - both in terms of understanding the opportunities for connecting people with landscape and developing adjunct agendas such as improving health and well-being. Such timely investigations would undoubtedly help to define a visionary, approach, which would go well beyond self-interested self-declarations and provide a meaningful foundation for the future of this potentially game-changing initiative.

\section{ACKNOWLEDGEMENT}

We would like to acknowledge the Catherine Cookson Foundation who provided funding for initial scoping research.

\section{REFERENCES}

[1] MacEachern, A., Who had America's Best Idea? Online. http://niche-canada.org/ 2011/10/23/who-had-americas-best-idea/.

[2] National Parks England: National Breathing Spaces. Online. www.nationalparksengland.org.uk/home/about-national-parks-england/policy.

[3] Khan, S., Manifesto for London. Online. www.sadiq.london/a_greener_ cleener_london.

[4] National Parks England, National Parks for National Health. Online. www.nationalparksengland.org.uk/news-and-media/press-releases/national-parksfor-national-health.

[5] Atonovsky, A., Health, Stress and Coping, Jossey-Bass Publishers: San Francisco, 1979.

[6] Cooper, R., Burton, E. \& Cooper, G.L., (eds), Wellbeing: A Complete Reference Guide Volume II, Wellbeing and the Environment, Wiley-Blackwell: Chichester, 2014.

[7] Natural England, Natural England's Green Infrastructure Guidance (NE176). Online. http://publications.naturalengland.org.uk/publication/35033.

[8] Gesler, W., Therapeutic landscapes: Theory and a case study of Epidauros, Greece. Environment and Planning D: Society and Space, 11(2), pp. 171-189, 1993. DOI: 10.1068/d110171.

[9] Gesler, W., Healing Places, Rowman and Littlefield: New York, 2003.

[10] Williams, A., (eds), Therapeutic Landscapes, Ashgate: Aldershot, 2007.

[11] Hartig, T., Mitchell, R., De Vries, S. \& Frumkin, H., Nature and health. Annual Review Public Health, 35(1), pp. 207-228, 2004. DOI: 10.1146/annurev-publhealth-032013182443.

[12] Ulrich, R.S., Aesthetic and affective response to natural environment. Behavior and the Natural Environment, eds. I. Altman \& J.F. Wohwill, Plenum Press: New York, pp. 85-125, 1983.

[13] Ulrich, R.S., Simons, R.F., Losito, B.D., Fiorito, E., Miles, M.A. \& Zelson, M., Stress recovery during exposure to natural and urban environments. Journal of Environmental Psychology, 11(3), pp. 201-230, 1991. DOI: 10.1016/s02724944(05)80184-7.

[14] Kaplan, R. \& Kaplan, S., Experience of Nature, Cambridge University Press: New York, 1989.

[15] Kaplan, S., The restorative benefits of nature: Toward an integrative framework. Journal of Environmental Psychology, 15(3), pp. 169-182, 1995. DOI: 10.1016/02724944(95)90001-2. 
[16] Townshend, T.G., Urban Parks for Human Health and Well-being. Reti e infrastrutture dei territori contemporanei, eds. F.D. Moccia \& M. Sepe, INU Edizioni: Roma, 2016.

[17] Laumann, K., Garling, T. \& Stormark, K.M., Rating scale measures of restorative components of environments. Journal of Environmental Psychology, 21(1), pp. 31-44, 2004. DOI: $10.1006 /$ jevp.2000.0179.

[18] van den Bosch, M., Impacts of urban forests on physical and mental health and wellbeing. Routledge Handbook of Urban Forestry, eds. F. Ferrini, C.C.F. van den Bosch \& A. Fini, Routledge: Abingdon, 2017.

[19] Pealmutter, D., Sanenesi, G. \& O'Brien, L., (eds), The Urban Forest: Cultivating Green Infrastructure for People and the Environment, Springer International Publishing, 2017.

[20] Lafortezza, R., Carrus, G., Sanesi, G. \& Davies, C., Benefits and well-being perceived by people visiting green spaces in periods of heat stress. Urban Forestry Urban \& Greening, 8(2), pp. 97-108, 2009. DOI: 10.1016/j.ufug.2009.02.003.

[21] Davies, C. et al., Guideline for urban forestry as critical green infrastructure in European urban areas, 2017.

[22] Han, K., A reliable and valid self-rating measure of the restorative quality of natural environments. Landscape Urban Planning, 64(4), pp. 209-232, 2003. DOI: 10.1016/s0169-2046(02)00241-4.

[23] Herzog, T.R., A cognitive analysis of preference for waterscapes. Journal of Environmental Psychology, 5(3), pp. 225-241, 1985. DOI: 10.1016/s02724944(85)80024-4.

[24] Korpela, K.M. \& Hartig, T., Restorative qualities of favorite places. Journal of Environmental Psychology, 16(3), pp. 221-233, 1996. DOI: 10.1006/jevp.1996.0018.

[25] White, M., Smith, A., Humphreys, K., Pahl, S., Snelling, D. \& Depledge, M., Blue space: The importance of water for preference, affect and restorativeness ratings of natural and built scenes. Journal of Environmental Psychology, 30(4), pp. 482-493, 2010. DOI: 10.1016/j.jenvp.2010.04.004.

[26] Townshend, T.G., Urban Bluespace for human flourishing. Waterfront Urban Space: Designing for Blue-Green Places, ed. D. Babalis, Altralinea Edizioni: Firenze.

[27] Curtis, S., Space, Place and Mental Health, Ashgate Publishing: Aldershot, 2010.

[28] Mayer, S.F. \& Frantz, C.M., The connectedness to nature scale: A measure of individuals' feeling in community with nature. Journal of Environmental Psychology, 24(4), pp. 503-515, 2004. DOI: 10.1016/j.jenvp.2004.10.001.

[29] Adjei, P.O.-W. \& Agyei, F.K., Biodiversity, environmental health and human wellbeing: Analysis of linkages and pathways. Environmental Development and Sustainability, 17(5), pp. 1085-1102, 2015. DOI: 10.1007/s10668-014-9591-0.

[30] Li, Q. et al., Visiting a forest, but not a city, increases human natural killer activity and expression of anti-cancer proteins. International Journal of Immunopathology Pharmacology, 21(1), pp. 117-127, 2008. DOI: 10.1177/039463200802100113.

[31] Rook, G.A., Regulation of the immune system by biodiversity from the natural environment: An ecosystem service essential to health. Proceedings of the National Academy of Sciences of the United States of America, 110(46), pp. 18360-18367, 2013. DOI: $10.1073 /$ pnas.1313731110.

[32] Louv, R., Last Child in the Woods: Saving Our Children from Nature-Deficit Disorder, Atlantic Books, Workman: New York, 2010.

[33] Lozano, E., Visual needs in the built environment. Town Planning Review, 45(3), pp. 351-374, 1974.

[34] Smith, P.F., Familiarity breeds contentment. The Planner, 60, pp. 901-904, 1974. 
[35] Grenville, J., Conservation as psychology: Ontological security and the built environment. International Journal of Heritage Studies, 13(6), 447-461, 2007. DOI: 10.1080/13527250701570614.

[36] Brown, B.B. \& Perkins, D., Disruptions in place attachment. Place Attachment, eds. I. Altman \& S. Low, Plenum Press: New York, pp. 279-304, 1992.

[37] Wells, J.C. \& Baldwin, E.D., Historic preservation, significance, and age value: A comparative phenomenology of historic Charleston and the nearby new-urbanist community of I'On. Journal of Environmental Psychology, 32(4), pp. 384-400, 2012. DOI: 10.1016/j.jenvp.2012.06.002.

[38] Williamson, K.S., Growing with Green Infrastructure, Heritage Conservancy: Doylestown, 2003.

[39] CABE, Does Money Grow in Trees? CABE: London, 2005.

[40] Konijnendijk, C.C., A decade of urban forestry in Europe. Forest Policy and Economics, 5(2), 173-186, 2003. DOI: 10.1016/s1389-9341(03)00023-6.

[41] GHK, Social and Economic Benefits of the Natural Environment: Review of Evidence, 2006.

[42] Marmot, M., Fair society, health lives: The Marmot review, 2010. Online. www.instituteofhealthequity.org/resources-reports/fair-society-healthy-lives-themarmot-review/fair-society-healthy-lives-full-report-pdf.pdf.

[43] Roe, M., Townshend, T., Davies, C., Ward-Thompson, C., Gulsrud, N. \& Qin, Q., Urban National Parks, or National Park Cities, Town and Country Planning, (forthcoming, 2018).

[44] Mayor of London, All London Green Grid. Online. www.london.gov.uk/what-wedo/environment/parks-green-spaces-and-biodiversity/all-london-green-grid.

[45] Murray, R., The Royal National City Park, Stockholm, World Urban Parks Website. Online. www.worldurbanparks.org/en/news-events/news/322-parks-of-the-world-theroyal-national-city-park-stockholm-sweden. Accessed on: 10 Dec. 2015.

[46] Uggla, Y., Protecting urban greenery: The case of Stockholm's National City Park. City \& Community, 13(4), pp. 360-380, 2014. DOI: 10.1111/cico.12085.

[47] Keim, B., Our era's iconic national park is hidden in New York City, Grist. Online. https:/grist.org/cities/our-eras-iconic-national-park-is-hidden-in-new-york-city/. Accessed on: Aug. 23. 